\title{
Saw Dust Ash as Partial Replacement for Cement in Concrete
}

\author{
A. A. Raheem \\ Department of Civil Engineering, \\ Ladoke Akintola University of Technology \\ Ogbomoso, Oyo State, Nigeria \\ raheemayinde@yahoo.com
}

\author{
B. S. Olasunkanmi \\ Department of Civil Engineering, \\ Ladoke Akintola University of Technology \\ Ogbomoso, Oyo State, Nigeria \\ toondhay@gmail.com
}

\author{
C. S. Folorunso \\ Department of Civil Engineering, \\ Ladoke Akintola University of Technology \\ Ogbomoso, Oyo State, Nigeria \\ urimbakersintl@yahoo.com
}

DOI 10.5592/otmcj.2012.2.3

Research paper

THIS RESEARCH CONSIDERED THE USE OF SAW DUST ASH AS A POZZOLAN IN THE PRODUCTION OF CONCRETE. the study investigated the physical properties and chemical composition of saw dust ash (SDA) as well as the workability, and compressive strength properties of the concrete produced by replacing $5 \%, 10 \%, 15 \%, 20 \%$ and $25 \%$ by weight of ordinary Portland cement with SDA. Slump and compacting factor tests were carried out on the fresh concrete and compressive strength test on hardened concrete. The concrete cubes were tested at the ages of 3, 7, 28, 56 and 90 days. The results showed that SDA is a good pozzolan with combined $\mathrm{SiO}_{2}, \mathrm{Al}_{2} \mathrm{O}_{3}$ and $\mathrm{Fe}_{2} \mathrm{O}_{3}$ of $73.07 \%$. The slump and compacting factor decreased as the SDA content increased indicating that concrete becomes less workable as the SDA content increased. The compressive strength decreased with increasing SDA replacement. The compressive strength of concrete with SDA was lower at early stages but improves significantly up to 90 days. An optimum value of $23.26 \mathrm{~N} / \mathrm{mm} 2$ at 90 days was obtained for concrete with $5 \%$ SDA replacement. It was concluded that $5 \%$ SDA substitution is adequate to enjoy maximum benefit of strength gain.

\section{INTRODUCTION}

Keywords

Saw dust ash, Pozzolan, Workability, Compressive strength
There is need for affordable building materials in providing adequate housing for the teaming populace of the world. The cost of conventional building materials continue to increase as the majority of the population continues to fall below the poverty line. Thus, there is the need to search for local materials as alternatives for the construction of functional but low-cost buildings in both the rural and urban areas. Some of the local materials that have been used are earthen plaster (Svoboda and Prochazka, 2012), lateritic interlocking blocks (Raheem et al., 2012) and Palm kernel shell (Raheem et al., 2008).

Continuous generation of wastes arising from industrial by-products and agricultural residue, create acute environmental problems both in terms of their treatment and disposal. The con- 
struction industry has been identified as the one that absorbs the majority of such materials as filler in concrete (Antiohos et al., 2005). If these fillers have pozzolanic properties, they impart technical advantages to the resulting concrete and also enable larger quantities of cement replacement to be achieved (Hossain, 2003). Appropriate utilization of these materials brings ecological and economical benefits.

Saw dust is a waste material from the timber industry. It is produced as timber is sawn into planks at saw mills located in virtually all major towns in the country. This process is a daily activity causing heaps of saw dust to be generated after each day. The need to convert this waste product into a useful by-product is the focus of the study.

Some industrial wastes have been studied for use as supplementary cementing materials such as Fly ash (Siddique, 2004; Wang and Baxter, 2007; Wang et al., 2008), Silica fume (Lee et al., 2005; Turker et al., 1997), Pulverized fuel ash (Balendran and MartinBuades, 2000), Volcanic ash (Hossain, 2005), Rice husk ash (Waswa-Sabuni et al. 2002) and Corn cob ash (CCA) (Adesanya and Raheem, 2009a; 2009b; 2010; Raheem and Adesanya, 2011; Raheem et al. 2010). Literature is however scarce on the use of saw dust ash.

Elinwa and Ejeh (2004) considered the effect of the incorporation of waste incineration fly ash (SWIFA) in cement pastes and mortar. Cheah and Ramli (2011) investigated the implementation of wood waste ash as a partial cement replacement material in the production of structural grade concrete and mortar. Elinwa et al. (2008) assessed the fresh concrete properties of selfcompacting concrete containing sawdust ash. Elinwa and Mahmoodb (2002) considered ash from timber waste as cement replacement material. The present study considered both fresh and hardened properties of normal concrete in which saw dust ash is incorporated at the point of mix.

\begin{tabular}{|c|c|c|c|c|c|c|}
\hline \multirow[b]{2}{*}{ Sample } & \multicolumn{5}{|c|}{ Mix proportions $\left(\mathrm{kg} / \mathrm{m}_{3}\right)$} & \multirow[b]{2}{*}{$\mathbf{w} / \mathbf{b}$} \\
\hline & Cement & $\begin{array}{c}\text { Sawdust } \\
\text { ash }\end{array}$ & $\begin{array}{c}\text { Fine } \\
\text { aggregate }\end{array}$ & $\begin{array}{c}\text { Coarse } \\
\text { aggregate }\end{array}$ & Water & \\
\hline Control & 21.48 & 0 & 42.96 & 85.92 & 10.74 & 0.50 \\
\hline SDA-5 & 20.41 & 1.074 & 42.96 & 85.92 & 10.74 & 0.50 \\
\hline SDA-10 & $19 \cdot 33$ & 2.158 & 42.96 & 85.92 & 10.74 & 0.50 \\
\hline SDA-15 & 18.26 & 3.222 & 42.96 & 85.92 & 10.74 & 0.50 \\
\hline SDA-20 & 17.18 & 4.296 & 42.96 & 85.92 & 12.89 & 0.65 \\
\hline SDA-25 & 16.11 & $5 \cdot 370$ & 42.96 & 85.92 & 12.89 & 0.65 \\
\hline
\end{tabular}

Table 1 Mix proportions for SDA concrete

The study was performed in Nigeria which is in South-East Europe. The country has thick forests with abundant tree from which saw dust is obtained during processing. Thus, there is an abundant raw material for the research.

The current practice with saw dust is as fuel for domestic cooking and for sand filling ditches in which case it constitutes environmental nuisance. Converting the waste product - saw dust, into a useful by product - saw dust ash (SDA), has dual benefits. Environmental pollution is controlled and job is created for our teaming unemployed youths who could become agents for supplying the SDA to concrete industries that needed it. In the long run, the use of SDA as partial replacement for cement is expected to bring about reduction in the cost of concrete production since cement is the most expensive constituent of concrete.

This study examined the use of saw dust ash as partial replacement for ordinary Portland cement in concrete. It involves the determination of the chemical composition of the ash and evaluation of the workability, and compressive strength of the concrete.

\section{Materials and Method \\ Materials}

The saw dust used for this study was collected from saw mill points at Apake in Ogbomoso, Oyo State, Nigeria. The Sample was carefully collected to avoid mixing the saw dust with sand. The collected sample was burnt into ashes by open burning in a metal container. The saw dust ash (SDA) was ground after cooling using mortar and pestle. The yield calculation was done and tests were carried out to determine the physical and chemical properties of the SDA. The SDA was taken to Lafarge Cement, West Africa Portland Cement Company (WAPCO) Sagamu, Ogun State, Nigeria, for chemical analysis using X-ray fluorescent analyser (Model QX 1279). The SDA particles passing through sieve of aperture $425 \mu \mathrm{m}$ was used for this study.

The Ordinary Portland cement (Dangote, Brand) used was obtained around under $\mathrm{G}$ area in Ogbomoso. Sharp sand was used as fine aggregates and granite with maximum size of $20 \mathrm{~mm}$ as coarse aggregates. The fine and coarse aggregates used were obtained from a local supplier in $0 \mathrm{~g}$ bomoso, Nigeria.

\section{Specimen Preparation}

SDA was used to replace ordinary Portland cement at 5\%, 10\%, 15\%, 20\% and $25 \%$ by weight of cement. Concrete with no SDA present serves as the control experiment. The mix ratio used was 1:2:4 (binder, sand and granite) with water to binder ratio of 0.5 which was later increased to 0.6 . Table 1 showed the mix proportion for each category of SDA concrete. 


\begin{tabular}{|c|c|c|c|c|}
\hline \multirow{2}{*}{ Chemical constituents } & \multicolumn{4}{|c|}{ Percentage composition (\%) } \\
\hline & Sample 1 & Sample 2 & Sample 3 & Average \\
\hline $\mathrm{SiO}_{2}$ & 65.42 & 66.05 & 65.79 & 65.75 \\
\hline $\mathrm{Al}_{2} \mathrm{O}_{3}$ & 5.69 & 5.12 & 4.88 & 5.23 \\
\hline $\mathrm{Fe}_{2} \mathrm{O}_{3}$ & 2.16 & 2.09 & 2.01 & 2.09 \\
\hline $\mathrm{CaO}$ & 9.82 & 9.65 & $9 \cdot 39$ & 9.62 \\
\hline $\mathrm{MgO}$ & 4.23 & 4.11 & 3.92 & 4.09 \\
\hline $\mathrm{SO}_{3}$ & 1.09 & 1.20 & 0.98 & 1.09 \\
\hline $\mathrm{Na} 2 \mathrm{O}$ & 0.04 & 0.08 & 0.07 & 0.06 \\
\hline $\mathrm{K}_{2} \mathrm{O}$ & 2.38 & 2.22 & 2.68 & 2.43 \\
\hline $\mathrm{CaCO}_{3}$ & 7.89 & 7.32 & 8.54 & 7.92 \\
\hline LOI & 4.89 & 4.05 & 3.95 & $4 \cdot 30$ \\
\hline LSF & 1.09 & 1.98 & 2.07 & 1.71 \\
\hline SR & 10.53 & 11.03 & 10.45 & 10.67 \\
\hline$A R$ & 11.35 & 12.88 & 12.73 & 12.32 \\
\hline Total $\mathrm{SiO}_{2}+\mathrm{Al}_{2} \mathrm{O}_{3}$ & 71.11 & 71.17 & 70.67 & 70.98 \\
\hline Total $\mathrm{SiO}_{2}+\mathrm{Al}_{2} \mathrm{O}_{3}+\mathrm{Fe}_{2} \mathrm{O}_{3}$ & 73.27 & 73.26 & 72.68 & 73.07 \\
\hline
\end{tabular}

Table 2 Chemical composition of SDA

\begin{tabular}{|c|c|c|c|c|}
\hline Specific Gravity & $\begin{array}{c}\text { Loose bulk } \\
\text { Density }\left(\mathrm{kg} / \mathrm{m}^{3}\right)\end{array}$ & $\begin{array}{c}\text { Loss in Ignition } \\
(\%)\end{array}$ & Yield (\%) & $\begin{array}{c}\text { Moisture } \\
\text { Content (\%) }\end{array}$ \\
\hline $\begin{array}{c}2.19 \\
\text { years }\end{array}$ & 1040 & 4.30 & 3.00 & 0.30 \\
\hline
\end{tabular}

Table 3 Physical properties of saw dust ash (SDA)

Slump and compacting factor tests were carried out to check the effect of SDA on the workability of fresh concrete. The tests were carried out in accordance with the requirements of BS 1881: Part 102 (1983) for slump test and BS 1881: Part 103 (1983) for compacting factor test.

Specimen preparation for compressive strength test was performed using $150 \mathrm{~mm}$ cube steel moulds. The specimens were cast in three layers, each layer being tamped with 35 strokes of the tamping rod spread uniformly over the cross section of the mould. The top of each mould was smoothened and leveled and the outside surfaces cleaned. The moulds and their contents were kept in the curing room at temperature of $27 \pm 5^{\circ} \mathrm{C}$ and relative humidity not less than $90 \%$ for 24 hours.
De-moulding of the cubes took place after 24 hours and the specimens were transferred into water bath maintained at $27 \pm 5^{\circ} \mathrm{C}$ in the curing room. Compressive strength was determined at curing age $3,7,28,56$, and 90 days. The compressive strength was determined using compression machine with maximum capacity of $1500 \mathrm{kN}$ (Model 50- C34AC and Serial no 02094910). The strength value was the average of three specimens.

\section{Results and Discussion \\ Chemical Composition}

Table 2 shows the elemental oxides present in the SDA sample. The result showed that SDA has combined percentages of $\left(\mathrm{SiO}_{2}+\mathrm{Al}_{2} \mathrm{O}_{3}+\mathrm{Fe}_{2} \mathrm{O}_{3}\right)$ of $73.07 \%$ which is more than $70 \%$, indi- cating that it is a good pozzolanic material in accordance with the requirements in ASTM C 618 (1991). The SDA has slightly lower silica content with a $\mathrm{SiO}_{2}$ of $65.75 \%$ as against that of SWIFA which is $67.20 \%$ (Elinwa and Ejeh, 2004) and CCA with a value of $66.38 \%$ (Adesanya and Raheem, 2009a).

\section{Physical Properties of SDA}

Figure 1 shows the grading curve of the SDA. The curve falls within the sand zone of the particle size distribution curve stretching from the fine division to the coarse division. The result showed that SDA contains $55 \%$ of particles in the fine sand division. The material falls within zone 2 of the grading curve according to Elinwa and Ejeh [2004].The specific gravity, yield and other physical properties of SDA are presented in Table 3. The result shows a specific gravity of 2.19 which is lesser than that of cement which has a specific gravity of 3.01 .

\section{Sieve Analysis of Aggregates}

The results of the sieve analysis for fine and coarse aggregates are presented in Figures 2 and 3 respectively. It could be observed from Figure 2 that the coefficient of uniformity $\left(C_{u}\right)$ and coefficient of curvature $\left(C_{C}\right)$ for fine aggregates are 4.95 and 1.24 respectively. Thus, the sand can be said to be well graded (Smith and Smith, 1998). Similarly, the $\mathrm{C}_{\mathrm{u}}$ and $\mathrm{C}_{\mathrm{c}}$ for coarse aggregates are 0.89 and 1.75 respectively as obtained from Figure 3. This shows that the granite is uniformly graded (Smith and Smith, 1998). It can be concluded that the fine and coarse aggregates are suitable for making good concrete.

\section{Workability}

The results of the slump and compacting factor, indicating the workability of the SDA concrete are shown in Table 4. The table indicates that the slump value decreases as the SDA content increases. The compacting factor also decreases as the SDA content increases. 


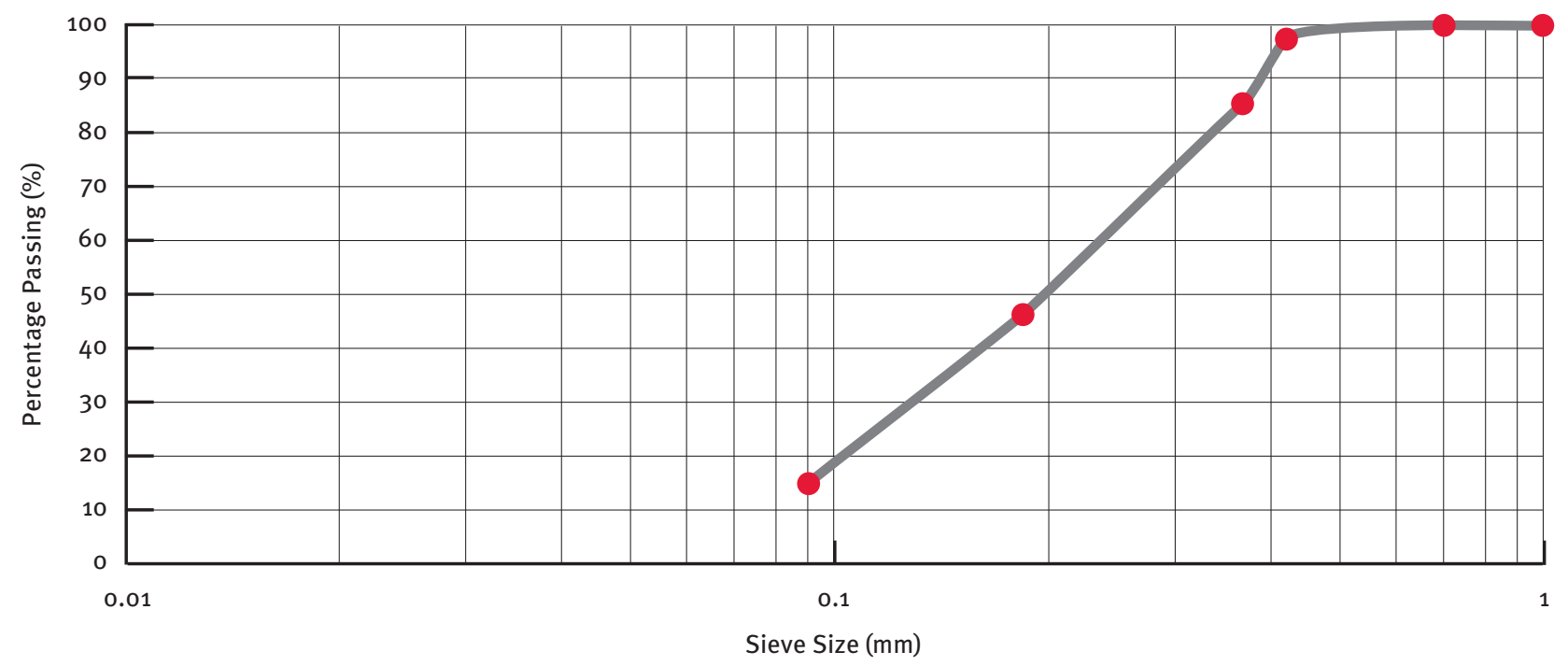

Figure 1: Particle Size Distribution Curve for SDA

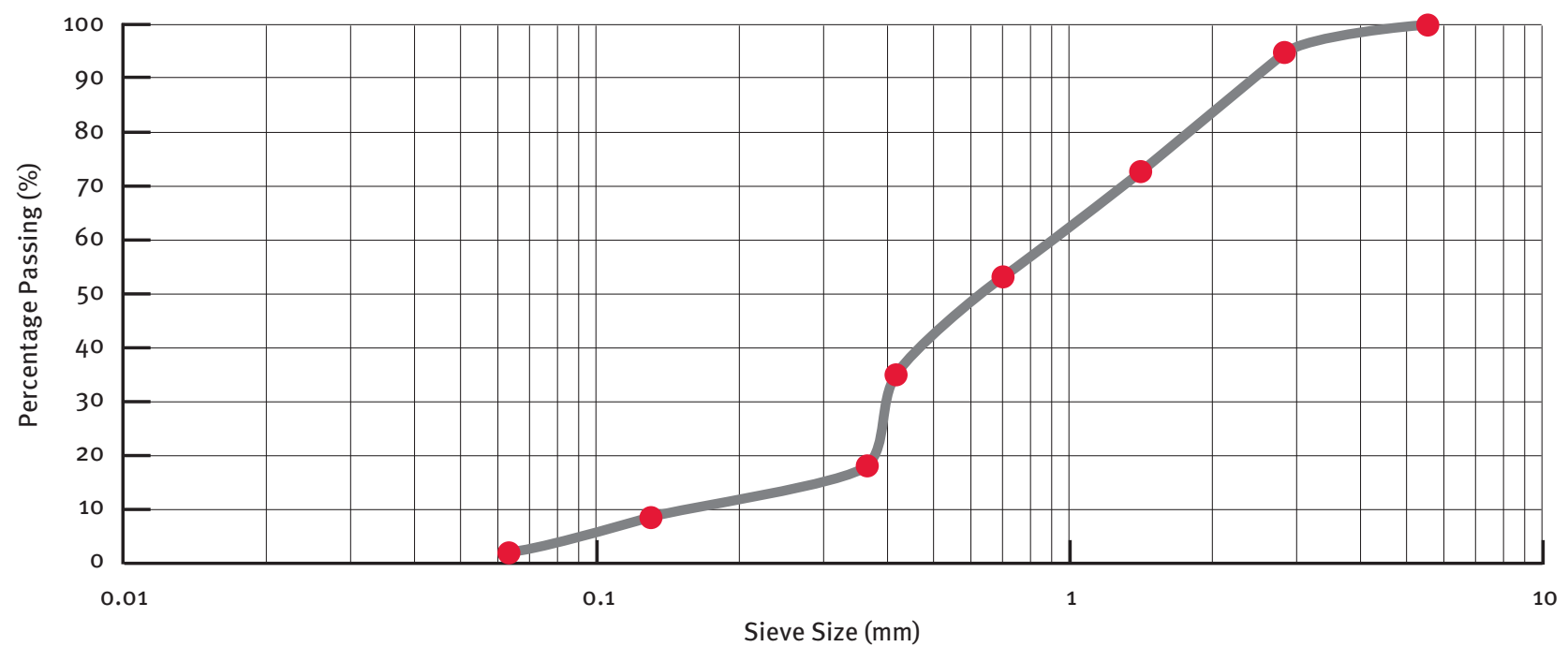

Figure 2: Particle Size Distribution Curve for Fine Agregates

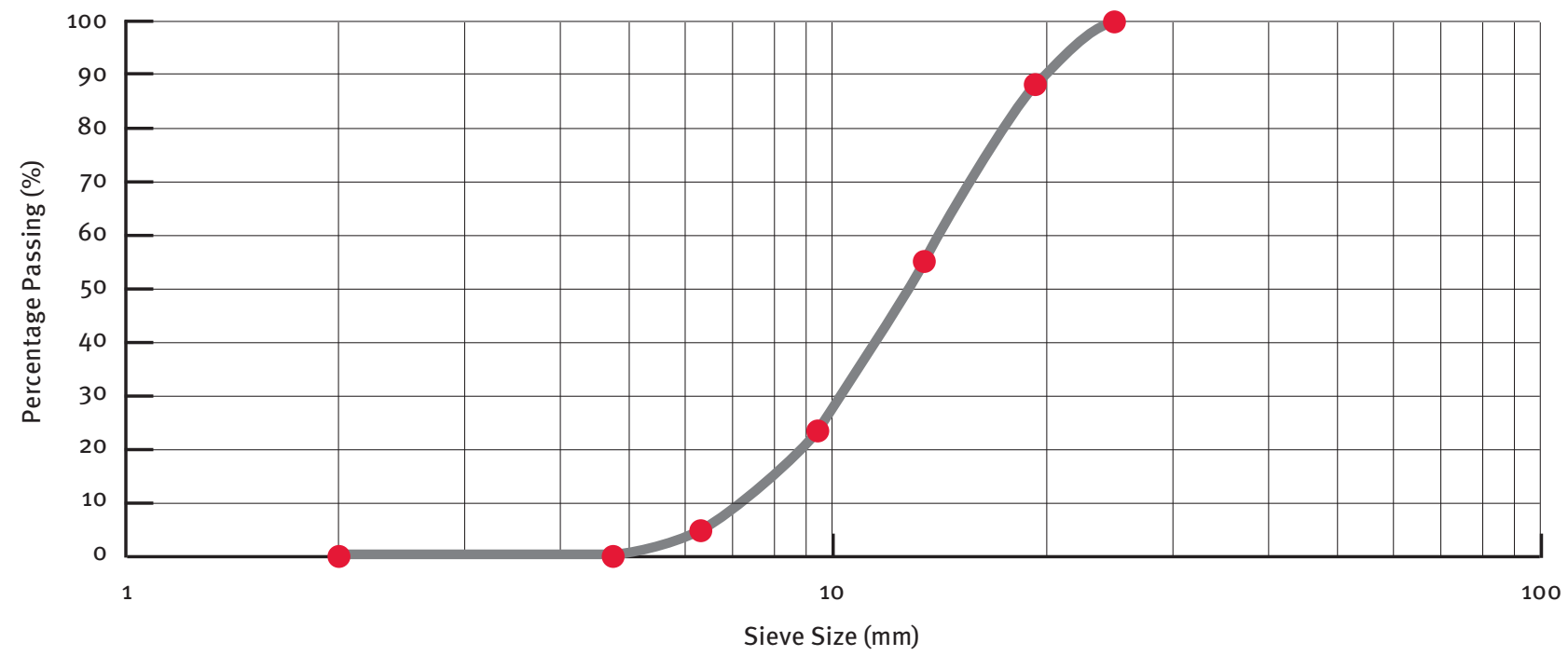

Figure 3: Particle Size Distribution Curve for Coarse Agregates 
From these results, it was noticed that concrete became less workable as the SDA percentage increases meaning that more water is required to make the mixes more workable. This was what led to increasing the water binder ratio from 0.5 to 0.6 for the $20 \%$ and $25 \%$ substitution since the mix was becoming stiff.

The high demand for water as SDA increases is due to increased amount of silica in the mixture. This is typical of pozzolan cement concrete as the silica-lime reaction requires more water in addition to the water needed during hydration of cement (Hague and Kayali, 1998; Waswa-Sabuni et al. 2002; Adesanya and Raheem, 2009a).

\section{Compressive Strength}

The effect of curing ages on the compressive strength of SDA concrete is presented in Figure 4. The figure indicates that compressive strength generally increases with curing period and decreases with increased amount of SDA.

The result at 3 days showed a decrease in strength from $14.22 \mathrm{~N} / \mathrm{mm}^{2}$ for control to $5.41 \mathrm{~N} / \mathrm{mm}^{2}$ for $25 \%$ SDA replacement. Similar trend was observed at 7 days as shown in Figure 4. These results indicate that concrete containing

\begin{tabular}{|c|c|c|}
\hline $\begin{array}{c}\text { Percentage SDA } \\
\text { replacement (\%) }\end{array}$ & $\begin{array}{c}\text { Slump } \\
(\mathrm{mm})\end{array}$ & Compacting factor \\
\hline 0 & 110 & 0.94 \\
\hline 5 & 100 & 0.94 \\
\hline 10 & 100 & 0.93 \\
\hline 15 & 95 & 0.92 \\
\hline 20 & 95 & 0.91 \\
\hline
\end{tabular}

Table 4 Slump and compacting factor values of SDA Concrete

SDA gain strength slowly at early curing age. This is in line with previous findings that concrete containing pozzolanic materials gained strength slowly at early curing ages (Hossain, 2005; Adesanya and Raheem, 2009a).

At 28 days, there was continuous increase in compressive strength for all the classes of concrete with values raging from $2052 \mathrm{~N} / \mathrm{mm}^{2}$ for the control, to $7.48 \mathrm{~N} / \mathrm{mm}^{2}$ for $25 \%$ SDA replacement. The control still has the highest compressive strength at this age.

The result at 56 days indicated that pozzolanic action had commenced as evident from the higher percentage increase in compressive strength by SDA concrete over that of the control. The percentage increase with respect to the
28 day strength for control was 3.61\%, while it was $21.87 \%, 5.99 \%, 7.94 \%$, $0.80 \%$ and $9.89 \%$ for $5 \%, 10 \%, 15 \%$, $20 \%$ and $25 \%$ SDA replacements. This increase in compressive strength can be attributed to the reaction of SDA with calcium hydroxide liberated during the hydration of cement.

At 90 days, there was significant improvement in strength development beyond 56 days as shown in Figure 4. The percentage increase in strength from 28 to 90 days was between $18.82 \%$ and $63.57 \%$. Higher percentage increases in strength than at 56 days were observed confirming the cement that continues to hydrate. However, the significant increase in strength of SDA concrete is due to the pozzolanic reaction of SDA.

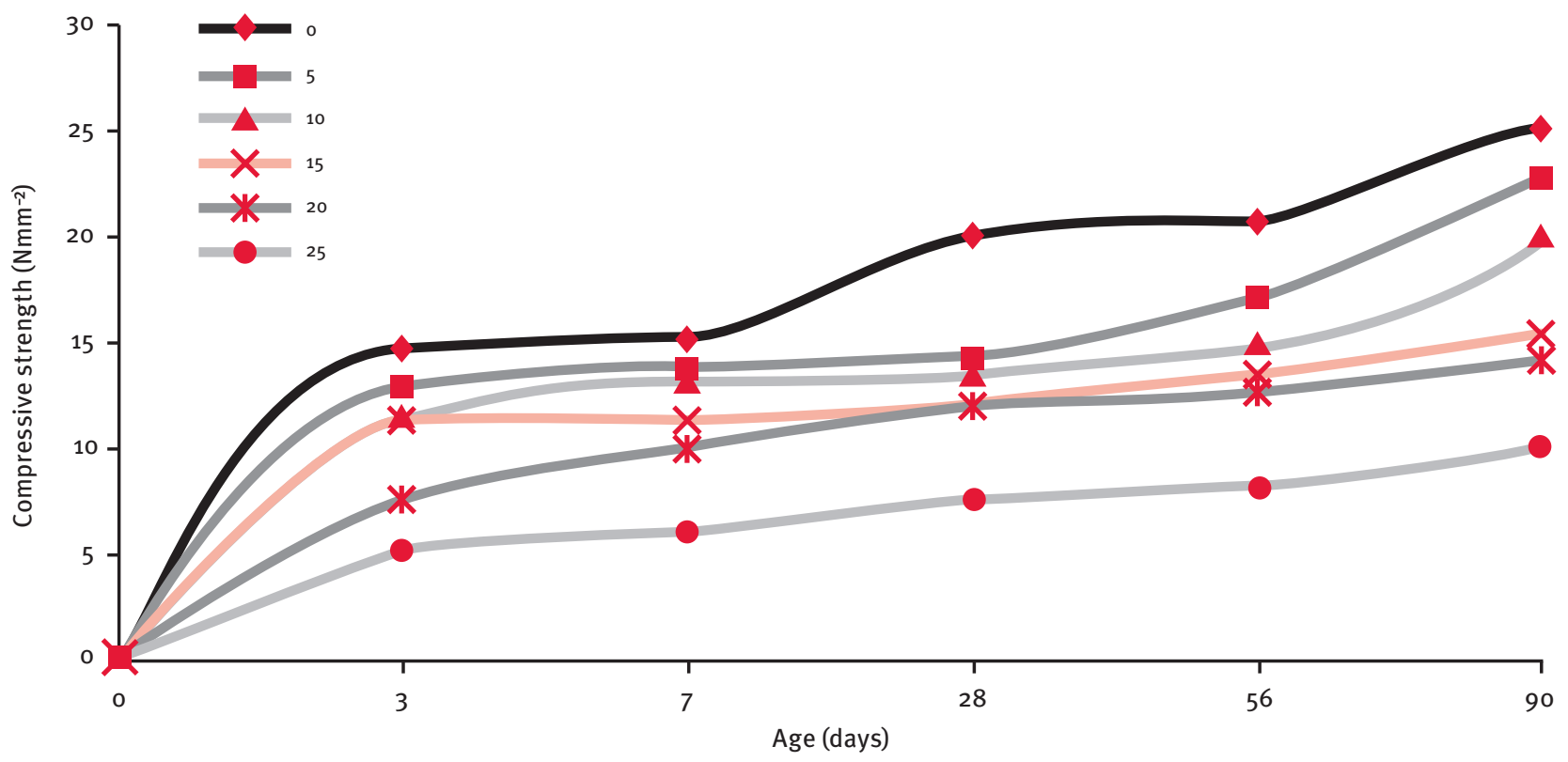

Figure 4: Effect of curing age on the compressive strength of SDA concrete 
The strength gain can be attributed to the cementitious products formed as a result of hydration of cement and those formed when lime reacts with the pozzolan incorporated (Balendran and MartinBuades, 2000; Adesanya and Raheem, 2009a). An optimum value of $23.26 \mathrm{~N} /$ $\mathrm{mm}^{2}$ at 90 days was obtained for concrete with $5 \%$ SDA replacement. It was concluded that $5 \%$ SDA substitution is adequate to enjoy maximum benefit of strength gain.

Figure 5 showed the effect of SDA percentage replacement on the compressive strength of concrete. As could be observed from the figure, there is a general decrease in compressive strength as the SDA content increases. Since all the specimens meet the minimum strength of $6 \mathrm{~N} / \mathrm{mm}^{2}$ after 28 days of curing recommended by BS 5224 (1976) for masonry cement, SDA concrete could be used for general concrete works where strength is of less importance such as in mass concrete, floor screed and mortar.

\section{Conclusion}

From the results of the various tests performed, the following conclusions can be drawn:

SDA is a suitable material for use as a pozzolan, since it satisfied the requirement for such a material by having a combined $\left(\mathrm{SiO}_{2}+\mathrm{Al}_{2} \mathrm{O}_{3}+\mathrm{Fe}_{2} \mathrm{O}_{3}\right)$ of more than $70 \%$.

Concrete becomes less workable as the SDA percentage increases meaning that more water is required to make the mixes more workable. This means that SDA concrete has higher water demand.

The compressive strength generally increases with curing period and decreases with increased amount of SDA. Only $5 \%$ SDA substitution is adequate to enjoy maximum benefit of strength gain.

\section{Acknowledgements}

The authors acknowledge the management and staff of Lafarge Cement, West Africa Portland Cement Company (WAPCO) Sagamu Works, Ogun State, Nigeria; for the opportunity given to perform the various laboratory tests using their facilities.

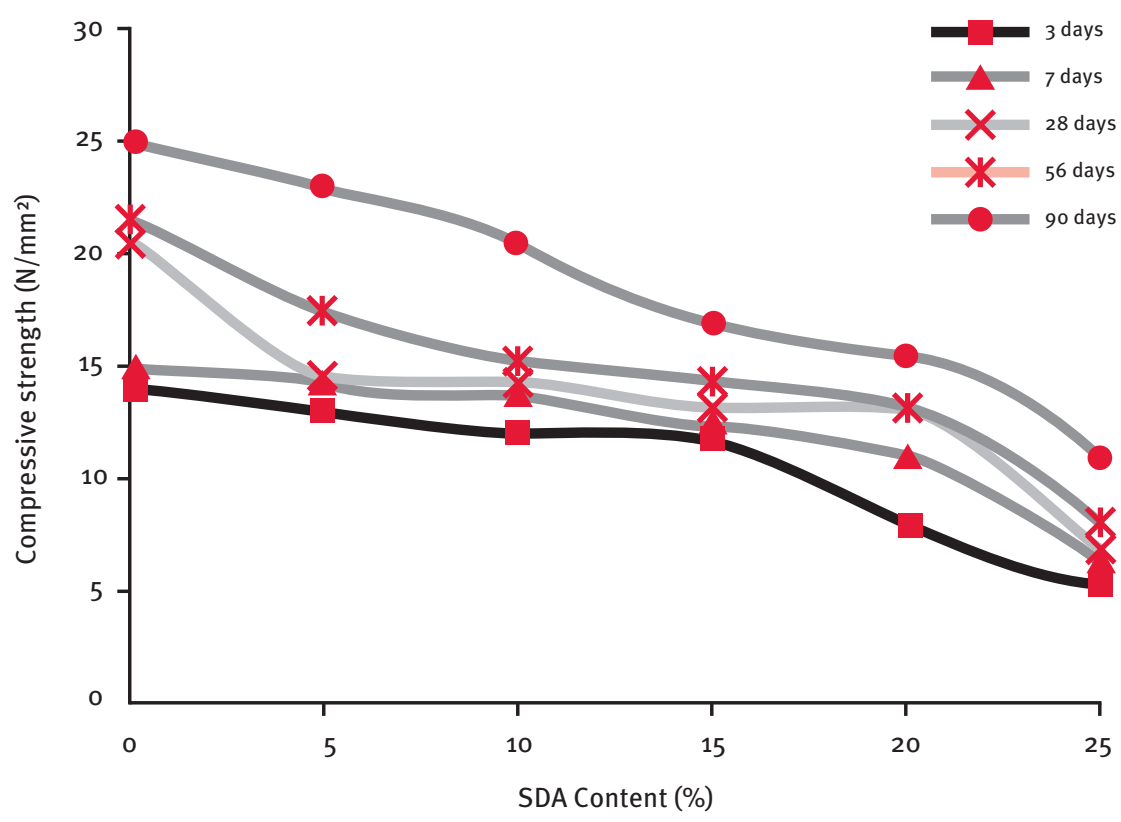

\section{References}

Adesanya, D. A. and Raheem, A. A. (2009a), "A study of the workability and compressive strength characteristics of corn cob ash

blended cement concrete", Construction and Building Materials, Vol. 23, pp. 311-317.

Adesanya, D. A. and Raheem, A. A. (2009b), "Development of corn cob ash blended cement", Construction and Building Materials; Vol. 23, pp. 347-352.

Adesanya, D. A. and Raheem, A. A. (2010),

"A study of the permeability and acid attack of corn cob ash blended cements", Construction and Building Materials,

Vol. 24, pp. 403- 409.

Antiohos, S.; Maganari, K.; Tsimas, S. (2005),

"Evaluation of blends of high and low calcium fly ashes for use as supplementary cementing materials", Cement \& Concrete Composites, Vol. 27, pp. 349-356.

ASTM C 618 (1991), Standard Specification for Fly Ash and Raw or Calcined Natural Pozzolan for use as a Mineral Admixture in Portland Cement Concrete, Annual Book of ASTM Standards, Philadelphia, USA.

Balendran, R. V. and Martin-Buades, W. H. (2000), "The influence of high temperature curing on the compressive, tensile and flexural strength of pulverized fuel ash concrete", Building and Environment, Vol. 35 No.5, pp.415-423.

BS 1881: Part 102 (1983), Methods for determination of Slump, British Standard Institution, London.

BS 1881: Part 103 (1983), Methods for determination of Compacting factor, British Standard Institution, London.

BS 5224 (1976), Standard Specification for Masonry Cement, British Standard Institution, London.

Cheah, C. B. and Ramli, M. (2011) “The implementation of wood waste ash as a partial cement replacement material in the production of structural grade concrete and mortar: an overview Review Article, Resources, Conservation and Recycling, Vol. 55 Issue 1, pp. 669-685

Elinwa. A. U. and Mahmoodb, Y. A. (2002) "Ash fron timber waste as cement replacement material, Cement and Concrete Composites, Vol. 24 Issue 2, pp. 219-222.

Elinwa, A. U. and Ejeh, S. P. (2004), “Effects of the incorporation of sawdust waste incineration fly ash in cement pastes and

Figure 5: Effect of saw dust ash (SDA) replacement on the compressive strength of concrete 
mortars", Journal of Asian Architecture and Building Engineering, Vol. 3 No.1, pp.1-7.

Elinwa, A. U.; Ejeh, S. P. and Mamuda,

A. M. (2008) "Assessing of the fresh concrete properties of self-compacting concrete containing sawdust ash, Construction and Building Materials, Vol. 22 Issue 6, pp. 1178-1182.

Hague, M. N. and Kayali, O. (1998), "Properties of High-Strength Concrete using a Fine Fly Ash", Cement and Concrete Research, Vol. 28 No.10, pp. 1445-1452.

Hossain, K. M. A. (2003), “Blended Cement using Volcanic Ash and Pumice”, Cement and Concrete Research, Vol. 33, pp. 1601-1605.

Hossain, K. M. A. (2005), “Chloride induced corrosion of reinforcement in volcanic ash and pumice based blended concrete", Cement \& Concrete Composites, Vol. 27, pp. 381-390.

Lee, S.; Moon, H. Y. and Swamy R. N. (2005), "Sulfate attack and role of silica fume in resisting strength loss”, Cement \& Concrete Composites, Vol. 27, pp. 65-76.

Raheem, A. A.; Nwakanma, E. O. and Ogunleye, K. O. (2008) “Engineering Properties of Concrete with Palm Kernel Shell as Fine and Coarse Aggregates", USEP, Journal of Research Information in Civil Engineering (RICE), Vol. 5 No.1, pp. 58-70.

Raheem, A. A.; Oyebisi, S. O.; Akintayo, S. O. and Oyeniran, M. I. (2010), "Effects of admixtures on the properties of corn cob ash cement concrete", Leonardo Electronic Journal of Practices and Technologies, Vol. 16, pp.13-20.

Raheem, A. A. and Adesanya, D. A. (2011), "A study of thermal conductivity of corn cob ash blended cement mortar", The Pacific Journal of Science and Technology, Vol.12 No. 2, pp. $106-111$.
Raheem, A. A.; Falola, O. O. and Adeyeye, K. J. (2012) "Production and Testing of Lateritic Interlocking Blocks”, Journal of Construction in Developing Countries, Malaysia, Vol.17 No.1, pp. 35-50.

Siddique, R. (2004), “Performance characteristics of high-volume Class F fly ash concrete", Cement and Concrete Research, Vol. 34 No.3, pp. 487-493.

Smith, G. N. and Smith, Ian G. N. (1998), Elements of Soil Mechanics, Seventh Edition, Blackwell Science, London.

Svoboda, P. and Prochazka, M. (2012) "Outdoor earthen plasters", Organisation, Technology and Management in Construction: an International Journal, Vol. 4 No. 1, pp.420-423.

Turker, F.; Akoz, F.; Koral, S. and Yuzer, N. (1997), “Effects of Magnesium sulfate concentration on the sulfate resistance of mortars with and without silica fume", Cement and Concrete Research, Vol. 27, pp. 205-214.

Wang, S. and Baxter, L. (2007), "Comprehensive study of biomass fly ash in concrete: Strength, microscopy, kinetics and durability", Fuel Processing Technology, Vol. 88, pp. 1165-1170.

Wang, S.; Miller, A.; Llamazos, E.; Fonseca, F. and Baxter, L. (2008), "Biomass fly ash in concrete: Mixture proportioning and mechanical properties”, Fuel, Vol. 87, pp. 365-371.

Waswa-Sabuni, B.; Syagga, P. M.; Dulo, S. O. and Kamau, G, N. (2002), “Rice Husk Ash Cement - An Alternative Pozzolana Cement for Kenyan Building Industry”, Journal of Civil Engineering, JKUAT, Vol. 8, pp. 13-26. 